\title{
Factors Affecting Nutritional Status among Children Aged 12-23 Months
}

\author{
Tisnasari Hafsah, ${ }^{1}$ Lina Shabrina Qorib Sudaryo, ${ }^{2}$ Yovi Yoanita ${ }^{3}$ \\ ${ }^{1}$ Department of Child Health Faculty of Medicine Universitas Padjadjaran/Dr. Hasan Sadikin \\ General Hospital Bandung, Indonesia, ${ }^{2}$ Faculty of Medicine Universitas Padjadjaran, Indonesia, \\ ${ }^{3}$ Department of Public Health Faculty of Medicine Universitas Padjadjaran, Indonesia
}

\begin{abstract}
Background: In Indonesia about 18\% of children, mostly in the first two years of life, are malnourished, causing a serious impact. Many factors are thought to affect nutritional status among young children. This study was conducted to determine factors affecting the nutritional status of children aged 12-23 months in West Java, Indonesia.

Methods: This cross-sectional study used secondary data obtained from a Basic Health Research (Riset Kesehatan Dasar, RISKESDAS) 2010, conducted by Badan Penelitian dan Pengembangan Kesehatan (BALITBANGKES) Ministry of Health Republic of Indonesia. All of the data among children aged 12-23 months in West Java province was obtained. Statistical relationships between predisposing factors and nutritional status i.e. weight for height were analyzed using the chi-square test.

Results: In total, 730 data were obtained, of which 567 data met the inclusion criteria. Malnutrition was detected in $101(17.8 \%)$ children. There was a significant relationship ( $\mathrm{p}=0.017,0 \mathrm{R}=2.6,95 \%$ CI 1.1-5.8) between low birth weight and nutritional status. Nevertheless, no significant relationship was found between nutritional status and history of exclusive breastfeeding $(p=0.629)$, complimentary feeding ( $\mathrm{p}=0.949)$, vitamin A ( $\mathrm{p}=0.209)$, infectious diseases $(\mathrm{p}=0.266)$, complete immunization status $(\mathrm{p}=0.420)$, and mother education level $(\mathrm{p}=0.251)$.

Conclusions: The low birth weight is the only significant factor associated with the nutritional status among children less than 2 years old; resulting in that low birth weight had a 2.6 higher chance of malnutrition in the early years. Other factors are unexpectedly not significant in this study. There is thus a need to improve the quality of programs, focusing on childbearing mothers, during antenatal control.
\end{abstract}

Keywords: Low birth weight, nutritional status, malnutrition, RISKESDAS 2010, West Java

\section{Introduction}

Nutrition is a key component of development in children. Fulfillment of adequate nutrition will help children to survive, to grow healthy, to avoid illness, and to develop excellent intellectual, emotions, and behavior. ${ }^{1,2}$ Most optimal growth in children occurs between the beginning of pregnancy and the first two years of life, which period is called the window of opportunity or a critical window. ${ }^{3}$ Malnutrition during this period may cause a serious impact on growth and development in children, which is harder to restore when given a late intervention. ${ }^{1,4}$

Many factors are thought to affect the nutritional status of children. The previous study has shown that the important determinants of the incidence of child malnutrition are infant feeding practice, immunization status, growth monitoring, birth weight, and maternal education. ${ }^{5}$ Micronutrient deficiency especially in children may also increase the risk of infectious diseases. ${ }^{6}$ Stimulation of the immune response when exposed to infection may increase energy requirements affecting nutritional status in children. ${ }^{6}$

There is abundant data collected from Riset Kesehatan Dasar (RISKESDAS) 2010, which

Correspondence: Tisnasari Hafsah, Department of Child Health, Faculty of Medicine, Universitas Padjadjaran/ Dr. Hasan Sadikin General Hospital, Jalan Pasteur No. 38 Bandung, Indonesia, Email: tisnasari_hafsah@yahoo.com 
can be studied thoroughly. In this survey, it has been shown that $17.9 \%$ of infants in Indonesia are still malnourished. ${ }^{7}$ Therefore, we were intrigued to study further to determine the factors that may affect the nutritional status among children under 2 years old, especially children in West Java Province.

\section{Methods}

The initial data was from a National Basic Health Research or RISKESDAS 2010, a national basic health survey conducted by Badan Penelitian dan Pengembangan Kesehatan (BALITBANGKES), Institution of Health Research and Development, under the Ministry of Health of the Republic of Indonesia. After obtaining permission and approval from the Ministry of Health, we analyzed the data from West Java Province. This secondary data was further analyzed to answer our research questions, to determine the factors that affected the nutritional status among children under 2 years old, especially children in West Java Province.

Data collection of RISKESDAS 2010 itself started in May 2010 to August 2010. In brief, this national survey employed two-stage cluster random sampling to select representative samples. The first phase was the selection of Census Blocks Group (BG), and the second stage was the selection of households. Each census block consisted of 25 households. From each province in Indonesia, several BGs were taken to represent household and household members in the area. The instrument for collecting household and individual data was questionnaires of RKD10.RT and RKD10.IND, which were filled out by trained and skillful interviewers, based on clear questionnaire guidelines.

For our study purpose, all of the data among children aged 12-23 months in West Java province was obtained. The dependent variable in this study was the nutritional status measured by the weight-for-height category. The status was further grouped into wasting nutritional status (Z-score $<-2.0)$ and normal nutritional status (Z-sore $\geq-2.0$ to $\leq$ 2.0). Data on overweight nutritional status (Z-score $>2.0$ ) was further excluded. The independent variables of this study were history of exclusive breastfeeding, complimentary feeding, administration of vitamin A, low birth weight (LBW), history of infectious diseases, complete immunization status, the frequency of weighing in the last six months, and the education of the mothers.

In accordance with the RISKESDAS 2010 survey, our study also used a cross-sectional design that observed and measured several risk factors as independent variables and particular outcomes as dependent variables. The statistical association between variables was analyzed using the chi-square test. Pvalues $<0.05$ were considered significant.

\section{Results}

From the original RISKESDAS data, data of 730 children aged 12-23 months in West Java were obtained from whom data of 163 children with overweight nutritional status (Z-score > 2.0) were excluded. The remaining data of 567 data of children aged below 2 years old in West Java had shown that the prevalence rate of malnutrition among boys (9.5\%) was similar to the corresponding prevalence among girls (Table 1). In total, 101 children $(17.8 \%)$ were

Table 1 The Nutritional Status among Children Aged 12-23 Months Old from West Java Province Based on Gender and Place of Origin.

\begin{tabular}{lccc}
\hline \multirow{2}{*}{ Sample Distribution } & \multicolumn{2}{c}{ Nutritional Status } & Total \\
\cline { 2 - 3 } & $\begin{array}{c}\text { Malnutrition } \\
\mathrm{n}(\%)\end{array}$ & $\begin{array}{c}\text { Normal } \\
\mathrm{n}(\%)\end{array}$ & \\
\hline Gender & $54(9.5 \%)$ & $249(43.9 \%)$ & 303 \\
$\quad$ Male & $47(8.3 \%)$ & $217(38.3 \%)$ & 264 \\
Female & & & \\
Place of origin & $32(5.6 \%)$ & $186(32.8 \%)$ & 218 \\
$\quad$ Rural area & $69(12.2 \%)$ & $280(49.4 \%)$ & 349 \\
$\quad$ Urban area & & & \\
\hline
\end{tabular}


Table 2 The Distributions of Risk or Predisposing Factors among Children Aged 12-23 Months in West Java

\begin{tabular}{|c|c|c|}
\hline Variables & Total (n) & Percentage (\%) \\
\hline \multicolumn{3}{|l|}{ Exclusive breastfeeding } \\
\hline No & 23 & 20.0 \\
\hline Yes & 92 & 80.0 \\
\hline \multicolumn{3}{|l|}{ Complimentary food } \\
\hline$<6$ months & 251 & 44.3 \\
\hline$\geq 6$ months & 316 & 55.7 \\
\hline \multicolumn{3}{|l|}{ Received vitamin A } \\
\hline No & 140 & 24.7 \\
\hline Yes & 427 & 75.3 \\
\hline \multicolumn{3}{|l|}{ Birth weight } \\
\hline$<2,500$ gr or low birth weight & 28 & 5.5 \\
\hline$\geq 2,500$ gr or normal & 477 & 94.5 \\
\hline \multicolumn{3}{|l|}{ History of infections } \\
\hline Yes & 56 & 9.9 \\
\hline No & 511 & 90.1 \\
\hline \multicolumn{3}{|l|}{ Immunization status } \\
\hline Not Complete & 63 & 23.7 \\
\hline Complete & 203 & 76.3 \\
\hline \multicolumn{3}{|c|}{ Frequency of weighing in the last 6 months } \\
\hline Not Regular (1-3 times) & 169 & 29.8 \\
\hline Regular (4-6 times) & 398 & 70.2 \\
\hline \multicolumn{3}{|l|}{ Education of mothers } \\
\hline Low & 430 & 93.3 \\
\hline High* $^{*}$ & 31 & 6.7 \\
\hline
\end{tabular}

Note: * High education was high school and above

malnourished. Based on the distribution of place of origin, as many as 218 children (38.4\%) were living in rural areas of which 32 children $(5.6 \%)$ had malnutrition. This percentage of malnutrition was lower than the proportion of children in urban areas $(12.2 \%)$. However, the place of origin only tended to show a significant difference ( $p>0.05)$.

Furthermore, 23 children $(20.0 \%)$ did not receive exclusive breastfeeding and 251 children $(44.3 \%)$ already started to consume complimentary food before the age of six months. There were still 63 children (23.7\%) who did not complete their immunizations. Maternal education level in West Java was low, with only 31 mothers (6.7\%) received a high education level which was high school and above) (Table 2).

Moreover, the only statistically significant risk factor of malnutrition was the low birth weight (LBW), with p=0.017 OR 2.6 (95\% CI 1.1-5.8), suggesting that low birth weight had 2.6 higher chance of malnutrition. As much as $35.7 \%$ of infants born weighing less than 2500 grams suffered from malnutrition. LBW infants were 2.6 times at higher risk to have malnutrition as compared to infants with normal weight (Table 3).

\section{Discussions}

The majority of infants with low birth weight (LBW) have poor growth in the first few days to weeks of their lives. Hence, when the normal 
Table 3 Associations between Risk or Predisposing Factors and Nutritional Status of Children Aged 12-23 Months in West Java

\begin{tabular}{|c|c|c|c|c|c|}
\hline \multirow[b]{2}{*}{ Predisposing Factors } & \multicolumn{2}{|c|}{ Nutritional Status } & \multirow[b]{2}{*}{ p-value } & \multirow{2}{*}{$\begin{array}{l}\text { Odds } \\
\text { Ratio } \\
(\mathrm{OR})\end{array}$} & \multirow{2}{*}{$\begin{array}{c}95 \% \\
\text { Confidence } \\
\text { Interval (CI) }\end{array}$} \\
\hline & $\begin{array}{c}\text { Malnutrition } \\
\text { n(\%) }\end{array}$ & $\begin{array}{c}\text { Normal } \\
\text { n(\%) }\end{array}$ & & & \\
\hline \multicolumn{6}{|l|}{ Exclusive breastfeeding } \\
\hline No & 5 (21.7) & $18(78.3)$ & 0.629 & nd & nd \\
\hline Yes & $16(17.4 \%)$ & $76(82.6 \%)$ & & & \\
\hline \multicolumn{6}{|l|}{ Complimentary food } \\
\hline$<6$ months & $45(17.9)$ & $206(82.1)$ & 0.949 & nd & nd \\
\hline$\geq 6$ months & $56(17.7)$ & $260(82.3)$ & & & \\
\hline \multicolumn{6}{|l|}{ Received vitamin A } \\
\hline No & $20(14.3)$ & $120(85.7)$ & 0.209 & nd & nd \\
\hline Yes & $81(19.0)$ & $346(81.0)$ & & & \\
\hline \multicolumn{6}{|l|}{ Birth weight } \\
\hline$<2,500$ gr or low birth weight & $10(35.7)$ & $18(64.3)$ & 0.017 & nd & nd \\
\hline$\geq 2,500$ gr or normal & $84(17.6)$ & $393(82.4)$ & & & \\
\hline \multicolumn{6}{|l|}{ History of infection } \\
\hline Yes & $13(23.2)$ & $43(76.8)$ & 0.266 & nd & nd \\
\hline No & $88(17.2)$ & $423(82.8)$ & & & \\
\hline \multicolumn{6}{|l|}{ Immunization status } \\
\hline Not Complete & $13(20.6)$ & $50(79.4)$ & 0.604 & nd & nd \\
\hline Complete & $36(17.7)$ & $167(82.3)$ & & & \\
\hline \multicolumn{6}{|l|}{$\begin{array}{l}\text { Frequency of weighing in the last } 6 \\
\text { months }\end{array}$} \\
\hline Not Regular (1-3 times) & $30(17.8)$ & $139(82.2)$ & 0.980 & nd & nd \\
\hline Regular (4-6 times) & $71(17.8)$ & $327(82.2)$ & & & \\
\hline \multicolumn{6}{|l|}{ Education of mothers } \\
\hline Low & $40(17.9)$ & $183(82.1)$ & 0.251 & nd & nd \\
\hline High* & $3(9.7)$ & $28(90.3)$ & & & \\
\hline
\end{tabular}

Note: nd was designated as not determined since $\mathrm{p}$-value was not a significant difference ( $\mathrm{p}>0.05$; chi-square test). ${ }^{*}$ High education was high school and above

infant starts to grow, they are left behind and have difficulty catching up as they do not get enough nutrition to produce adequate growth rates. ${ }^{8}$ Infants with a history of LBW require more nutrition for their growth. Although LBW infants are breast-fed or given formula milk, the total protein intake is often still not sufficient to lead them to the normal growth rate. ${ }^{9}$ Sometimes, even when the total protein intake is sufficient, a particular amino acid component could still be lacking and disrupt the protein balance. ${ }^{10}$ Additional supplements consisting of protein, fat, glucose, and zinc should be given in order to achieve optimum growth. ${ }^{8}$
The fact that infants with a history of LBW burn more energy than babies, in general, it complicates the situation. They need more energy to grow and to synthesize new tissue. The degree of heat exchange and evaporation on the skin of LBW infants are also higher. Quite often, these babies suffer from respiratory problems and infections or these babies are required to take certain drugs. For compensation, more intake is needed to produce more energy. ${ }^{11,12}$

Impaired growth in LBW infants may provide long-term effects that are not desirable. The children might be shorter than children in general and the history of malnutrition during 
the period of brain development can result in a decreasing number of brain cells as well as deficiencies in the behavior, the learning ability, and an impaired memory., 8,13-16

Prevention efforts should be carried out to reduce the incidence of LBW. It certainly can be done by improving prenatal care. ${ }^{17}$ Besides maintaining the nutritional intake, the mothers in childbearing age should avoid an unhealthy lifestyle, such as smoking, taking drugs, and alcohol. Interestingly, consuming progesterone hormone during pregnancy is proven to be effective in reducing the risk of delivering a pre-term baby in a woman with history premature birth..$^{18,19}$

A workshop has been conducted by the USA National Institute of Child Health and Human Development to answer questions about the nutritional needs of infants with a history of low birth weight and whether an earlier aggressive intake would help the baby to catch up. An early aggressive feeding has been suspected to bring a bad impact and instead would give a toxic effect on the baby's organs. However, the idea of supplementing the additional intake of macronutrients such as amino acids, glucose, and lipids as well as specific essential or nonessential amino acids such as insoles, choline, nucleotides is substantial to support an optimum growth. ${ }^{8}$

This study is lacking some aspects as this study has used secondary data, thus, missing data cannot be back-traced which reduce the number of data collected. Furthermore, several types of bias, such as information bias and confounding may also take part in this unexpected result. ${ }^{20}$

To conclude, our study has only shown that low birth weight is associated with the nutritional status among children aged 12-23 months in West Java province, resulting in that low birth weight has a 2.6 higher chance of malnutrition. There is thus a need to improve the quality of programs during antenatal control to raise awareness and knowledge about the pregnancy and early life of children.

\section{References}

1. UNICEF. Why early childhood development?. 2013. [Cited 2019 August 28]. Available from: http://www.unicef. org/earlychildhood/index_40748.html.

2. UNICEF Early childhood: the big picture. 2015 [Cited 2019 August 28]. Available from: http://www.unicef.org/ earlychildhood/index_bigpicture.html.

3. World Bank. Direction in development:
Repositioning nutrition as central to development: A Strategy for LargeScale Action. Washington DC: World Bank; 2006 [Cited 2019 August 28]; Available at: http://siteresources. world ban k. or g / N U T R I T I O N / Resources/281846-1131636806329/ NutritionStrategy.pdf.

4. Ashar T, Lubis Z, Aritonang E. Analisis pola asuh makan dan status gizi pada bayi di Kelurahan PB Selayang Medan. Komunikasi Penelitian-Rekayasa. 2008;1(2):66-73.

5. Anwar K, Juffrie M, Julia M. Faktor risiko kejadian gizi buruk di Kabupaten Lombok Timur Propinsi Nusa Tenggara Barat. Jurnal Gizi Klinik Indonesia. 2006:2(3):108-16

6. Schaible UE, Kaufmann SH. Malnutrition and infection: complex mechanisms and global impacts. PLoS Med. 2007;4(5):e115.

7. Badan Penelitian dan Pengembangan Kesehatan Kementerian Kesehatan Republik Indonesia. Laporan Nasional Riset Kesehatan Dasar (Riskesdas) Tahun 2010. Jakarta: Badan Penelitian dan Pengembangan Kesehatan. 2010.

8. Hay WW Jr, Lucas A, Heird WC, Ziegler E, Levin E, Grave GD, et al. Workshop Summary: nutrition of the extremely low birth weight infant. Pediatrics. 1999;104(6):1360-8.

9. Ziegler EE. Protein in premature feeding. Nutrition. 1994;10(1):69-71.

10. Rassin DK. Essential and non-essential amino acids in neonatal nutrition. In: Räihä NCR, editor. Protein metabolism during infancy. New York: Raven Press Ltd; 1994. p. 183-95.

11. Kalhan SC, Denne SC. Energy consumption in infants with bronchopulmonary dysplasia. J Pediatr. 1990;116(4):662-4.

12. Wahlig TM, Gatto CW, Boros SJ, Mammel MC, Mills MM, Georgieff MK. Metabolic response of preterm infants to variable degrees of respiratory illness. J Pediatr. 1994;124(2):283-8.

13. Hack M, Schluchter M, Cartar L, Rahman M, Cuttler L, Borawski E. Growth of very low birth weight infants to age 20 years. Pediatrics. 2003;112(1 Pt 1):e30-8.

14. Binkin NJ, Yip R, Fleshood L, Trowbridge FL. Birth weight and childhood growth. Pediatrics. 1988;82(6):828-34.

15. Hayakawa M, Okumura A, Hayakawa F, Kato Y, Ohshiro M, Tauchi N, et al. Nutritional state and growth and functional maturation of the brain in extremely low birth weight infants. Pediatrics. 2003;111(5 Pt 1):9915 . 
16. Casey PH, Whiteside-Mansell L, Barrett K, Bradley RH, Gargus R. Impact of prenatal and/or postnatal growth problems in low birth weight preterm infants on schoolage outcomes: an 8-year longitudinal evaluation. Pediarics. 2006;118(3):107886.

17. Goldenberg RL, Culhane JF. Low birth weight in the United States. Am J Clin Nutr. 2007;85(2):584S-90S.

18. da Fonseca EB, Bittar RE, Carvalho M, Zugaib M. Prophylactic administration of progesterone by vaginal suppository to reduce the incidence of spontaneous preterm birth in women at increased risk: a randomized placebo-controlled double-blind study. Am J Obstet Gynecol. 2003;188(2):419-24.

19. Meis PJ, Klebanoff M, Thom E, Dombrowski MP, Sibai B, Moawad AH, et al. Prevention of recurrent preterm delivery by 17 alphahydroxyprogesterone caproate. $\mathrm{N}$ Engl J Med. 2003;348(24):2379-85.

20. Jones S, Carley S, Harrison M. An introduction to power and sample size estimation. Emerg Med J. 2003;20(5):4538. 